\author{
BOGDAN JANKOWSKI ${ }^{1}$
}

\title{
Oddziaływanie Wspólnej Polityki Rolnej na ochronę środowiska
}

W końcu lat 90-tych w instrumentarium WPR pojawiły się nowe działania. Ich specyfika polegała głównie na innym podejściu do problemu nadwyżek produkcji rolnej w UE, a miały na celu wspomaganie realizacji jednego ze sposobów rozwiązania tego problemu - ekstensyfikacji produkcji rolnej. Działania te wiązały zmniejszenie wielkości produkcji rolnej z ochroną środowiska.

Nowoczesne techniki gospodarowania w rolnictwie, wspomagane systemem unijnych dopłat do produktu rolnego, powodowały z jednej strony niemalże lawinowy wzrost produkcji rolnej, z drugiej zaś znaczące obciążenie środowiska wynikające $\mathrm{z}$ intensyfikacji tej produkcji (intensywne nawożenie, monokultury, brak płodozmianu, chemizacja rolnictwa itp.).

Jak wiadomo, rolnictwo potrzebuje dobrych warunków środowiskowych do produkcji żywności o wysokiej jakości. Równocześnie intensywna gospodarka rolna silnie dewastuje to środowisko. Straty dotykają tutaj nie tylko wartości ekologicznych, ale również samej zdolności produkcyjnej rolnictwa, a zwłaszcza jakości produktów rolnych.

Dlatego też założenia konstrukcyjne wspomnianych nowych działań miały służyć połączeniu ochrony środowiska w działalności rolniczej z osiągnięciem efektu obniżenia intensywności produkcji rolnej, a tym samym odciążenia rynków rolnych, zmniejszenia nadprodukcji.

Niniejsze opracowanie ma na celu ocenę efektów środowiskowych wybranych instrumentów wspierania gospodarstw rolnych w Polsce od początku naszego członkostwa w UE. Warto tutaj zaznaczyć, że pomimo stosowania we wszystkich krajach członkowskich takiej samej puli instrumentacji WPR, gdy rzecz dotyczy wspólnej polityki strukturalnej w rolnictwie, każdy członek wspólnoty ma możliwości doboru tych instrumentów stosownie do lokalnych potrzeb oraz poprzez krajowe regulacje prawne odmiennie określić wymogi w stosunku do rolników. Dotyczy to także 
interesujących nas wymogów dotyczących zachowań prośrodowiskowych. W takiej sytuacji w każdym kraju członkowskim efektywność stosowania wspólnych instrumentów polityki strukturalnej może być różna.

W odniesieniu do warunków Polski widać potrzebę oceny szeregu działań WPR, które oddziałują bezpośrednio, bądź tylko pośrednio na jakość środowiska. Równocześnie nasza specyfika polega na tym, że oprócz wspomnianych wcześniej problemów środowiskowych związanych z intensyfikacją produkcji rolnej, mamy również problemy odmiennego rodzaju - wynikające z zaprzestania produkcji rolnej na gruntach marginalnych. ${ }^{2}$

Nadmierny nacisk na rozszerzanie terytorialne produkcji rolnej w minionych okresach zaowocował podejmowaniem tej produkcji na gruntach gorszej jakości, gdzie w warunkach rynkowych opłacalność jest niemożliwa. Sukcesywnie więc następowało wycofywanie się rolników z produkcji na takich użytkach. Sytuacja ta powoduje duże straty ekologiczne wynikające z pogorszenia się warunków bytowania zwierząt oraz zmniejszania się różnorodności biologicznej roślin uzależnionych od dotychczasowej produkcji rolnej. Przyroda samodzielnie nie potrafi przywrócić równowagi środowiskowej na terenach, gdzie przez lata prowadzono gospodarkę rolną, a potrzebuje na to długiego czasu, zwłaszcza gdy problem dotyczy gruntów najsłabszych.

Dzisiaj widać już, że największą rolę przy rozwiązaniu tego problemu środowiskowego odegrały niepodejrzewane o działanie prośrodowiskowe dopłaty bezpośrednie. Wymogi dobrej praktyki rolniczej w stosunku do producentów rolnych ubiegających się o dopłaty spowodowały, że do ekstensywnej gospodarki rolnej powracają grunty wcześniej ugorowane.

Po 2005 roku nastąpił znaczący spadek powierzchni ugorów i odłogów - z 6,5\% użytków rolnych do 2,9\% w 2008 roku. W latach 2000-2005 spadek ilości odłogów i ugorów wynosił tylko $0,7 \%$.

Na marginesie należy zauważyć, że taka pozytywna z punktu widzenia ochrony środowiska tendencja podejmowania ekstensywnej produkcji rolnej może być równocześnie negatywnie oceniana z powodu potrzeby zmian w strukturze własności gospodarstw rolnych. Dopłaty bezpośrednie przysługujące praktycznie wszystkim posiadaczom gruntów ograniczyły obrót nieruchomościami rolnymi pochodzącymi $\mathrm{z}$ małych nietowarowych gospodarstw rolnych. ${ }^{3}$

A. Bołtromiuk, Rozwój gospodarczy wsi a stan środowiska naturalnego-współzależności, konflikty i oddziaływania polityki, (w:) Raport o stanie wsi. Polska wieś 2012, red. J. Wilkin, I. Nużyńska, Warszawa 2012, s. 125 i nast.

3 J. Stosik. Instrumenty kształtowania struktury obszarowej gospodarstw rolnych w Polsce ze szczególnym uwzględnieniem roli instrumentów finansowych, „Studia luridica Agraria” 2011, t. 9, s. 218 i nast. 
Bez względna to czy mamy do czynienia $\mathrm{z}$ nadmierną intensyfikacją czy też z zaniechaniem upraw rolnych prowadzących do obciążenia środowiska, regulatorem zachowań rolników w zakresie korzystania ze środowiska są reguły cross-compliance - zasady zgodności środowiskowej. Te wymogi stosownych praktyk rolniczych ustalone co do zasady na poziomie wspólnotowym są uzależnione od rodzaju wspomagania, jakie otrzymuje beneficjent WPR. W odniesienu do działań, które związane są z ochroną środowiska, poziom tych wymogów jest szczególnie ważny zarówno w zakresie regulacji prawnych - wymogów formalnych, jak też na etapie ich stosowania - kontroli i egzekwowania ich stosowania.

Sytuacja w tym zakresie jest zróżnicowana; zależy od rodzaju działania, ale trzeba zauważyć, że wymogi cross-compliance przynajmniej na poziomie formalnym wzrastają w ostatnim okresie w odniesieniu do działań prośrodowiskowych. ${ }^{4}$

Spośród działań WPR należy wybrać te, które wywierają przynajmniej potencjalne skutki środowiskowe. Należą do nich:

1. Dostosowanie gospodarstw rolnych do standardów UE.

2. Wspieranie gospodarowania na obszarach górskich i innych obszarach o niekorzystnych warunkach gospodarowania $(\mathrm{ONW})$.

3. Program rolnośrodowiskowy.

4. Zalesianie gruntów rolnych oraz zalesianie gruntów innych niż rolne.

5. Odtwarzanie potencjału produkcji leśnej zniszczonego przez katastrofy oraz wprowadzanie instrumentów zapobiegawczych.

\section{Dostosowanie gospodarstw rolnych do standardów UE}

Jest to jedyne działanie spośród tu omawianych, które było realizowane w PROW 2004-2006, a nie ma swojej kontynuacji w obecnym programie. Realizacja tego działania opierała się wyłącznie na tzw. 3 standardach:

- przechowywanie nawozów naturalnych,

- standardy produkcji mleka,

- standardy ferm kur niosek.

W większości przypadków (90\% wniosków) rolnicy składali wnioski na standard pierwszy - finansowanie budowy płyty obornikowej i zbiorników na gnojówkę.

Z punktu widzenia jakości środowiska działanie to ma wielkie znaczenie w warunkach produkcji zwierzęcej wielkostadnej. Skoncentrowana emisja z gospodarstwa rolnego, głównie do wód gruntowych, ale również i do powietrza jest najbar- 
dziej szkodliwym środowiskowo zanieczyszczeniem dokonywanym przez tego typu rolnictwo intensywne.

Stąd wysoko należy ocenić efektywność środowiskową tego instrumentu, zwłaszcza że efekty zostały osiągnięte prostą regulacją i relatywnie niewielkimi środkami. 73 tysiące wniosków rolników zaowocowało zbudowaniem 70 tysięcy urządzeń służących bezpośrednio ochronie środowiska w zakresie intensywnej produkcji zwierzęcej. ${ }^{5}$

Pozostałe standardy w ramach tego działania, głównie ze względu na nikłe zainteresowanie rolników nie odegrały większej roli w ochronie środowiska.

\section{Wspieranie gospodarowania na obszarach górskich i innych obszarach o niekorzystnych warunkach gospodarowania (ONW)}

Instrument ten $\mathrm{w}$ założeniach prawodawstwa wspólnotowego pomyślany był jako wsparcie rolnictwa na tzw. terenach regresowych, gdzie szczególnie trudne warunki produkcji rolnej powodują jej nieopłacalność, a tym samym wyludnianie się tych terenów. W zakresie środowiskowym prowadzi to do znacznego pogorszenia warunków bytowania zwierząt dziko żyjących, spadku bioróżnorodności, zmian krajobrazowych itp. Dodatkowe wsparcie, poza rutynowymi dopłatami przysługującymi do każdego hektara użytków rolnych na takich obszarach regresowych, ma poprzez poprawę opłacalności odwrócić te niekorzystne tendencje,w tym również środowiskowe.

Realizacja tego instrumentu w Polsce jest jednakże szczególna ze względu na przyjęcie bardzo szerokiej formuły określania terenów regresowych. Poza objęciem dodatkową pomocą użytków rolnych na terenach górskich (4,2\% środków wydatkowanych w całym działaniu) oraz na obszarach ze specyficznymi naturalnymi utrudnieniami (9,2\% środków),pozostałe środki, tzn. 86,6\%, przeznaczono na pomoc dla obszarów nizinnych ONW. Tak więc głównymi beneficjentami tego działania stali się rolnicy którzy prowadzą gospodarstwa w gminie o negatywnym bilansie demograficznym oraz glebach o niższej jakości. Niewielkie wymogi uznania gminy za obszar ONW spowodowały, że w ramach tego działania pomocą objęto blisko 838 tys. gospodarstw rolnych działających na ponad 50\% użytków rolnych kraju.

Dodatkowo między płatnościami dla poszczególnych typów ONW jest, jak się wydaje, niedostateczne zróżnicowanie:

- obszary górskie - 320 zł/ha,

- obszary ze specyficznymi naturalnymi utrudnieniami - 264 zt/ha, wśród rolników. Wysokość finansowania ujęcia nawozów naturalnych ze środków PROW pozwalała poza kosztami inwestycji uzyskać jeszcze dodatkowy dochód w gospodarstwie rolnym. 
- obszary nizinne - 179 lub 264 zł/ha w zależności od położenia.

Bez porównania wyższe trudności gospodarowania na terenach górskich nie przekładają się na kompensację finansową. W każdej z tych kategorii ONW rolnik ma spełniać jedynie podstawowe wymagania dobrej praktyki rolniczej.

Oceniając efektywność środowiskową tego instrumentu należy, wskazać na jego dystrybucyjne, alimentacyjne zastosowanie. Tak duża ilość wspomaganych gospodarstw rolnych powoduje rozproszenie środków, efektem czego jest zbyt niskie wspomaganie gospodarstw działających w rzeczywiście trudnych warunkach oraz zbyt hojne dopłaty na terenach nizinnych. Dla większości rolników z tych obszarów dostateczne dla utrzymania ciągłości rolniczego gospodarowania, tym samym utrzymania walorów środowiskowych, byłyby powszechne dopłaty bezpośrednie, które jak wspomniano wcześniej, działają dostatecznie stymulująco na likwidację niekorzystnych dla środowiska odłogów i ugorów.

Alokacja środków do gospodarstw działających na prawdziwie regresowych obszarach pozwoliłaby równocześnie na zwiększenie wymogów zgodności środowiskowej, co byłoby szczególnie cenne, jako że gospodarstwa te są położone z reguły na obszarach wymagających zwiększonej ochrony środowiska.

Działanie w ramach ONW z punktu widzenia finansowego jest działaniem najkosztowniejszym w PROW 2007-2013. Przeznaczono nań blisko 2,5 mld euro, co stanowi około $20 \%$ środków wydatkowanych na wszystkie działania programu. W relacji do tak wysokich kosztów działania ONW bardzo nisko należy ocenić jego efektywność środowiskową, zwłaszcza w połączeniu z brakiem wymagań zgodności środowiskowej ponad te dotyczące ogółu rolników. Możemy tutaj mówić jedynie o dodatkowym wsparciu alimentacyjnym dla dużej grupy gospodarstw rolnych.

\section{Program rolnośrodowiskowy}

Działanie to w założeniu ma wpływać bezpośrednio na stan środowiska na terenach rolniczych. Zakres wymagań związanych z ochroną środowiska, jakie odnoszą się do rolników uczestniczących w tym programie, są uzależnione od tzw. pakietu, który zobowiązują się realizować. ${ }^{6}$

Wśród 9 pakietów, które może realizować rolnik największym zainteresowaniem cieszy się pakiet 3 „Ekstensywne trwałe użytki zielone”. Uczestniczy w nim obecnie 38916 gospodarstw rolnych. ${ }^{7}$ Wynika to, jak się wydaje, z niewielkich wy-

6 Określa je par. 4 rozporządzenia MRiRW z dnia 26 lutego 2009 r. w sprawie szczegółowych warunków i trybu przyznawania pomocy finansowej w ramach działania „Program rolnośrodowiskowy” objętego PROW 20072013 (Dz.U. Nr 33, poz. 262 z pózn. zm.).

7 Dane statystyczne oraz finansowe w niniejszym opracowaniu pochodzą opracowania MRiRW. Informacje na temat realizacji PROW 2007-2013, Warszawa 15 czerwca 2012. 
mogów, jakie są związane z realizacją tego pakietu: skoszenie łąki po 1 czerwca i usunięcie z łąki biomasy. Popularność tego pakietu oznacza jednakże znaczącą poprawę stanu środowiska na terenach marginalnych, gdzie odłogowane łąki zarastające krzewami i chwastami stawały się nieużyteczne dla lokalnej fauny i flory.

W takim przypadku uczestnictwo rolnika w tym pakiecie często oznaczało powrót do ekstensywnego użytkowania łąk i pastwisk na zasadzie uzyskiwania z tego tytułu zarówno płatności bezpośrednich, jak i rolnośrodowiskowych. ${ }^{8}$

Drugim co do popularności wśród beneficjentów jest pakiet 8 ,Ochrona gleb i wód". Aktualnie uczestniczy w nim 37990 gospodarstw. Uczestnictwo w tym pakiecie jest relatywnie łatwe, bo wymagania z nim związane dotyczą stosowania na gruntach ornych tzw. wsiewek poplonowych albo międzyplonu ozimego czy też międzyplonu ścierniskowego. ${ }^{9}$ Gremialne uczestnictwo rolników w tym pakiecie wynika przede wszystkim z faktu, że wyżej wymienione zabiegi na słabszych gruntach ornych wykonywali już wcześniej. Teraz z tego tytułu otrzymują dodatkowe środki. ${ }^{10}$ Tym niemniej przydatność środowiskowa tego pakietu nie ulega przez to pomniejszeniu.

Zaskoczeniem jest duża popularność pakietu 1 „Rolnictwo zrównoważone”. Uczestniczy w nim obecnie 17639 gospodarstw. Zobowiązanie rolnika obejmuje tutaj podjęcie działań dotyczących:

- ograniczenia nawożenia azotowego,

- opracowania i stosowania planu nawozowego,

- przestrzegania doboru i następstwa roślin w uprawach rolnych,

- niestosowania osadów ściekowych.

Za realizację takich zobowiązań rolnik otrzymuje dopłatę w wysokości 360 zł/ ha. Rolnicy zgłosili do tego pakietu 577000 ha, czyli blisko 4 razy większą powierzchnię użytków rolnych w stosunku do zaplanowanej.

Znaczenie środowiskowe rolnictwa zrównoważonego związanie jest głównie z poprawą jakości produktów rolnych tam produkowanych, dotyczy więc przede wszystkim konsumentów. Z punktu widzenia rolnika pakiet ten jest atrakcyjny w sytuacji, gdy na gruntach ornych prowadzono tradycyjnie ekstensywną gospodarkę rolną.

Na drugim biegunie, najmniej popularne wśród rolników są pakiety 4 i 5 dotyczące bezpośrednio ochrony przyrody „Ochrona zagrożonych gatunków pta-

$8 \quad$ Niemałych, bo wynoszących $500 \mathrm{z}$ /ha.

$9 \quad$ W każdym przypadku istotą tych działań jest utrzymanie wilgotności i przeciwdziałanie erozji gleb lekkich.

10 Od 330 do $750 \mathrm{z}$ /ha. 
ków i siedlisk przyrodniczych - poza obszarami Natura 2000 i na tych obszarach". Uczestnictwo w tych pakietach zgłosiło tylko 6780 gospodarstw, co stanowi 2,4\% planowanych, na obszarze 17,5\% planowanej powierzchni użytków rolnych. Relatywnie duże wymagania środowiskowe w stosunku do realizatorów tych pakietów nie zrównoważyły nawet wysokie kwoty dopłat sięgające $1400 \mathrm{zt} / \mathrm{ha}$ na obszarach Natura 2000.

Podobnie niskie zainteresowanie rolników dotyczy pakietu 9 „Strefy buforowe". Wymagania tego pakietu, takie jak utrzymywanie miedz śródpolnych, czy nienawożonych stref w pobliżu zbiorników wodnych ma duże znaczenie dla utrzymywania różnorodności biologicznej terenów rolnych, czy zapobiegania eutrofizacji wód.

Płatności za tego typu działania nie są jednakże dostatecznie wysokie i wynoszą 40-110 zł/100 mb. I prawdopodobnie takie płatności spowodowały, że do tej pory pakiet ten jest realizowany w 174 gospodarstwach rolnych, a długość tych stref wynosi jedynie $346 \mathrm{~km}$.

Spośród pozostałych pakietów programu rolnośrodowiskowego warto wskazać jeszcze na pakiet 2 „Rolnictwo ekologiczne” jako mający istotne znaczenie środowiskowe, zarówno w odniesieniu gleb i wód w gospodarstwie rolnym, jak też do środowiska konsumentów.

Środki finansowe wydatkowane na ten pakiet są do tej pory największe spośród wszystkich pakietów i wynoszą $468 \mathrm{mln}$ zł. Efektywność środowiskowa tego pakietu jest zbliżona do rolnictwa zrównoważonego, jednak przy znacznie wyższych wydatkach na rolnictwo ekologiczne (o $160 \mathrm{mln}$ zf) dotyczy on mniejszej powierzchni użytków rolnych (o 77 tys. ha).

Stąd wydaje się, że rolnictwo ekologiczne jest pakietem, który łączy w sobie oddziaływanie prośrodowiskowe z elementami wsparcia dochodowego ekstensywnej produkcji rolnej.

\section{Zalesianie gruntów rolnych oraz zalesianie gruntów innych niż rolne}

Założeniem tego działania była zachęta do wyłączania z produkcji rolnej najmniej przydatnych rolniczo gruntów, a równocześnie osiągnięcie skutków środowiskowych, takich jak zwiększenie udziału lasów w globalnym bilansie węgla, ograniczenie zmian klimatu, a w skali lokalnej wzmocnienie ekologicznej stabilności obszarów leśnych, zmniejszenie fragmentacji lasów i tworzenie korytarzy ekologicznych. 
Tak duże i zróżnicowane oczekiwania środowiskowe w stosunku do tego działania w znacznej mierze nie zostały spełnione. Wynika to, jak się wydaje, głównie $\mathrm{z}$ relatywnie niskiego zainteresowania rolników tym działaniem.

Wymagania stawiane tutaj rolnikom obejmowały:

- zalesienie gruntów,

- opieka nad zalesieniami,

- prowadzenie upraw leśnych przez co najmniej 15 lat.

W ramach PROW 2007-2013 zalesiono do tej pory nieco ponad 22 tys. ha, a od 2004 roku w sumie 40 tys. ha. Taki poziom zalesień nie spełnił założeń planistycznych, o czym świadczą chociażby wielokrotne ujemne realokacje środków z zalesiania na inne działania PROW. ${ }^{11}$ Podstawowym powodem niskiego uczestnictwa rolników w zalesianiu gruntów rolnych jest swoista konkurencja między łatwym dostępem rolników do dopłat bezpośrednich, nawet na gruntach o niskiej przydatności rolniczej, ale także do dopłat środowiskowych i innych, a kwotami uzyskanymi z tytułu zalesienia. Sam fakt uczestnictwa w tym działaniu wyłącza możliwości korzystania z innych świadczeń.

Tymczasem, jak można wnioskować chociażby z licznych tytułów dopłat środowiskowych, możliwości uzyskiwania dochodów z posiadania nieruchomości rolnej są znacznie większe niż te pochodzące $\mathrm{z}$ premii zalesieniowej. Zwłaszcza że w wielu dopłatach, takich jak np. ONW, czy łąki ekstensywne, wymagania w stosunku do rolników są minimalne, zaś przy zalesieniu wymogi są kategoryczne i kontrolowalne.

Tak więc zalesienia dokonane od początku funkcjonowania PROW nie mogły stać się podstawą doprowadzenia do znaczących zmian środowiskowych, ani tych klimatycznych, ani też w skali lokalnej, ekologicznej. Problemem pozostaje także w dalszym ciągu brak zalesień na glebach lekkich. Występujące tam straty azotu powodują zanieczyszczenie wód i ich eutrofizację.

\section{Odtwarzanie potencjału produkcji leśnej zniszczonego przez katastrofy oraz wprowadzanie instrumentów zapobiegawczych}

Specyfika tego działania związana jest z występowaniem w Polsce w ostatnich latach zdarzeń meteorologicznych, które doprowadziły do znaczących strat leśnośrodowiskowych. Stąd potrzeba odbudowy tych lasów oraz ich ochrony przed kolejnymi katastrofami. 
Beneficjentem tego działania są Nadleśnictwa Lasów Państwowych, do tej pory uczestnictwo w tym działaniu podjęło 271 jednostek. Zainteresowanie tym działaniem jest duże. W końcu 2011 roku KE wyraziła zgodę na realokację środków na rzecz tego działania - w sumie $130 \mathrm{mln}$ euro, w tym również przesunięto środki z zalesiania gruntów rolnych.

Oddziaływanie środowiskowe tego instrumentu można określić jako pośrednie, zwłaszcza że ponad 90\% wniosków dotyczy schematu II tego działania czyli wzmacniania zabezpieczeń przeciwpożarowych w lasach państwowych. Tak więc skuteczność środowiskowa jest tutaj trudna do oceny, zwłaszcza gdy tak niewielki odsetek środków jest przeznaczany bezpośrednio na odbudowę lasów.

Dodatkowym ograniczeniem efektywności tego działania jest jego znikome oddziaływanie na stan lasów prywatnych, które dokonuje się niejako przy okazji poprawy stanu bezpieczeństwa lasów państwowych. Dopiero od 2012 roku Minister Rolnictwa dopuścił do uczestnictwa w tym działaniu właścicieli lasów prywatnych. ${ }^{12}$ Wprowadzono $\mathrm{w}$ rozporządzeniu po raz pierwszy nowe kryteria wyboru, preferujące właścicieli lasów prywatnych.

Oddziaływanie środowiskowe przedstawionych w niniejszym opracowaniu działań PROW 2007-2013 należy ostatecznie ocenić zarówno z punktu widzenia zachowania dotychczasowych walorów środowiska, jak i przywracania elementów środowiska do stanu właściwego.

W każdym z tych zakresów ochrony środowiska dużą efektywność wykazują poszczególne pakiety programu rolnośrodowiskowego. Trzeba tu wskazać na pakiet 3. Ekstensywne trwałe użytki zielone, pakiet 1. Rolnictwo zrównoważone, pakiet 8. Ochrona gleb i wód, czy wreszcie pakiet 2. Rolnictwo ekologiczne.

Pozostałe pakiety programu rolnośrodowiskowego nie przynoszą dostatecznych efektów zwłaszcza w zakresie zachowania środowiska, z powodu relatywnie wysokich wymagań w stosunku do rolników i słabego ich uczestnictwa-pakiety 4 . i 5. Ochrona ptaków i siedlisk, albo też z powodu zbyt niskiego wsparcia finansowego - pakiet 9 . Strefy buforowe.

W tym miejscu należy zauważyć, że w odniesieniu do zmian w przyrodzie, jako elemencie środowiska, ocena skuteczności działań ochronnych powinna być formułowana w oparciu o badania długookresowe. Dotychczas nie mamy jeszcze dostatecznych danych z wyników badań przyrodniczych, które byłyby podstawą uogólnień weryfikujących skuteczność instrumentów PROW. 
Ocena z konieczności musi opierać się na wskaźnikach skali finansowania działań, jak też wymagań środowiskowych w stosunku do rolników. Gdy idzie o ten ostatni wskaźnik, widać ostatnio znaczny postęp.

Wymogi cross-compliance, zarówno na poziomie formalnym, jak i kontrolowania ich realizacji stają się coraz ważniejsze w odniesieniu do dopłat rolnośrodowiskowych, ale również ONW. ${ }^{13}$

Drugim zjawiskiem wartym odnotowania jest duże zróżnicowanie efektywności środowiskowej poszczególnych instrumentów ochronnych. Niewielkie programy jak: Dostosowanie do standardów UE, przyniosły niewspółmiernie duże efekty w porównaniu z tak kosztownymi działaniami jak ONW, gdzie efekty środowiskowe są praktycznie nieznaczne. ${ }^{14}$

Skuteczność ochrony środowiska zależy też od wzajemnych relacji między działaniami PROW. Nadmierna dostępność i „opłacalność” jednych działań, jak np. dopłaty bezpośrednie, ONW, czy niektóre płatności rolnośrodowiskowe, powodują nieskuteczność innych, mających nawet większe znaczenie w ochronie środowiska. Wśród tych relatywnie nieskutecznych działań należy wymienić zalesianie gruntów rolnych, czy też ochronę ptaków i siedlisk przyrodniczych na terenach rolnych (pakiet 4 i 5 programu rolnośrodowiskowego)

Zwiększenie skuteczności ochrony środowiska w ramach wspomagania działań rolników możliwe będzie zwłaszcza wobec perspektywy zmniejszenia finansowania w przyszłym okresie budżetowym, głównie poprzez zwiększenie wymagań zgodności środowiskowej. Skuteczne zwiększenie tych wymagań będzie zaś możliwe przy równoczesnym wzroście wysokości płatności dla rolników działających na rzecz środowiska.

Pojawiająca się już nieśmiało tendencja odejścia od dystrybucji środków WPR między wielu beneficjentów na rzecz ich alokacji w celu wzmocnienia efektów środowiskowych powinna być znacznie wzmocniona w przyszłych programach. Efektem powinno być osiągnięcie zrównoważonej gospodarki rolnej, zwłaszcza na terenach o dużych potrzebach w zakresie ochrony środowiska.

\footnotetext{
13 Znamienny był tutaj rok 2008, kiedy ARiMR wykryła najwięcej nieprawidłowości w zakresie zgodności środowiskowej. Skontrolowano 3\% pobierających dopłaty, wykryto zaś nieprawidłowości u 13901 beneficjentów na obszarze 36336 ha.

14 Nie dotyczy to obszarów prawdziwie regresowych, gdzie dla wzmocnienia efektów środowiskowych wydatkowanie środków należałoby jeszcze zwiększyć.
} 
ENVIRONMENT PRESERVATION IN COMMON AGRICULTURAL POLICY

Key words: implementation of sustainable agriculture, effectiveness of CAP instruments, agricurtural activity.

Agricultural activity to produce in high quality needs clean environment, but itselves a cause of intensive production, makes a big damage in environment. CAP gives to member states financial support to achieve sustainable agriculture. In Poland effectiveness of implementation of this activities depends on two factors: level of financial resource allocation, and level of cross - compliance requirements.

Different conditions of using this factors in practice gives us possibility to implement effective instruments like environmental agriculture, and passive instruments like payment for degressive areas of agriculture.

To achieve better results of spending CAP money for environment programs should be done resource allocation to farmers who can fill higher environment preservation requirements. 